\title{
Decision Support System for Selecting Sustainable Alternatives to Conventional Jet Fuel: Impact of Emissions, Production Costs and Carbon Pricing
}

\author{
Suresh Chandran ${ }^{1} \&$ Murugan Anandarajan ${ }^{2}$ \\ ${ }^{1}$ Department of Management, Drexel University, Philadelphia, USA \\ ${ }^{2}$ Department of Decision Sciences, Drexel University, Philadelphia, USA \\ Correspondence: Suresh Chandran, Department of Management, LeBow College of Business, Drexel University, \\ Gerri C. LeBow Hall, 3220 Market Street, PA 1910, Philadelphia, USA. E-mail: sc44@drexel.edu
}

Received: January 21, 2020 Accepted: February 24, $2020 \quad$ Online Published: March 3, 2020

doi:10.5539/jms.v10n1p83 URL: https://doi.org/10.5539/jms.v10n1p83

\begin{abstract}
The United States Environmental Protection Agency (EPA) in June 2015, took a step toward regulating carbon emissions from airlines, following an assessment that airlines contribute to climate change. On July 25, 2016, the final endangerment finding (Note 1) under section 231(a) (2) (A) of the Clean Air Act for aviation emissions was issued by the EPA. The European Union had issued a similar finding previously and had proposed implementing an emission trading scheme in which the airlines would be required to participate in a cap and trade scheme for emissions from jet fuel. Traditional jet fuel is derived from petroleum, whose price is volatile and depends on geopolitical stability. Fuel burn is a significant cost for airlines and affects their profitability and value. Fuel burn is also a significant source of greenhouse gas emissions. An investigation of alternatives to jet fuel and switching from conventional jet fuel based on varying emission profiles, production costs and varying carbon prices is therefore timely. We use a simple decision support system to examine the link between the life-cycle greenhouse gas emissions of a range of fuels, economic costs of production and varying carbon prices. This analysis should be of interest to regulators, traders, risk managers and executives in the airline industry as well as practitioners of sustainability management.
\end{abstract}

Keywords: airlines, aviation and alternate fuels, carbon emissions trading, sustainability management

\section{Introduction}

Petroleum products have always been the airlines' fuel of choice because they offer optimal characteristics in terms of energy content, performance, availability, ease of handling, and price. Plunging crude oil prices, which dropped from more than $\$ 100$ per barrel in June 2014 to around \$50 per barrel in April 2017, together with accelerating economic growth, sparked increased profits for all US airlines, and drove rosy forecasts for carriers' stocks. However, in October 2018, Brent crude touched $\$ 80$ a barrel, a 28\% increase in 2017's average price of $\$ 54$, leading to questions of profitability, before plunging back down to $\$ 50$ in December 2018 and trading in September 2019 at around $\$ 60$ a barrel.

Jet fuel, derived from crude oil, accounts for as much as one-third of an airline's expenses. However, this cost has varied greatly over the past five years. In 2014, US airlines spent more than $\$ 46$ billion on about 16.2 billion gallons of jet fuel, according to the US Department of Transportation. Lower prices meant that airlines globally spent $\$ 70$ billion less on fuel in 2015 compared to 2014, reducing spending by one-third, according to the rating agency Moody's (Aviation Week, February 2015). With collapsing crude prices and improved GDP growth worldwide, airlines in 2015 posted their most robust margins in five years. Airline profitability increased dramatically. US carriers had a more than a three-fold increase in profits from a year earlier and collective global net profits of $\$ 33$ billion in 2015, up from \$16.4 billion in 2014 (International Air Transportation Association [IATA] Press Release No. 58, December 2015). According to the International Air Transport Association (IATA), this increase reflected the net impact of several global factors including improving economic prospects, record load factors, lower oil prices and the major appreciation of the US dollar. Fuel still represents a significant proportion of the industry's operating cost structure and the drop in oil prices was a major contributor to the airlines' profitability. Of course, low oil prices are not expected to last forever. Indeed, in June 2016, the IATA 
stated that airlines were nearing the peak of the positive stimulus from lower oil prices (IATA Press Release No. 27, June 2016). In fact, crude oil prices moved from a low of $\$ 30$ per barrel in January 2016 to $\$ 53$ per barrel in January 2017 to $\$ 80$ in October 2018. It was projected that airline margins in 2018 were likely to be squeezed as oil prices increased and fuel costs rose to $23 \%$ of airline revenue in 2018 vs. $17 \%$ of revenue in 2017 (Center for Aviation, 2018).

In June 2019, the IATA changed its 2019 outlook for the global air transport industry from a $\$ 35.5$ billion profit forecast to $\$ 28$ billion. It also stated that the business environment for airlines had deteriorated with rising fuel prices and a substantial weakening of world trade (IATA Press Release No. 27, June 2019). In 2019 overall costs were expected to grow by $7.4 \%$, outpacing a $6.5 \%$ rise in revenues. As a result, net margins were expected to be squeezed to $3.2 \%$ (from $3.7 \%$ in 2018). Similarly, profits per passenger were expected to decline to $\$ 6.12$ (from $\$ 6.85$ in 2018).

This volatility in the price of oil, combined with global warming concerns, regulatory changes, and energy security concerns has prompted the industry to explore alternatives to traditional fuel. When considering alternative fuels, the safe and reliable operation of the engine and aircraft are paramount. The environmental effects of any alternate fuels considered must include emissions from the engine and also the lifecycle effects associated with the production and use of the alternate fuel.

Research into alternative fuels was initially conducted in the 1970s when fuel prices increased as a result of the energy crisis. Most of this work was on the conversion of biomass to fuel. However, for widespread, routine use, only petroleum-derived jet fuels were found to be economically practical. Traditional jet fuel is derived from petroleum, whose price is volatile and depends on geopolitical stability. Fuel burn is a significant source of airline expense that affects profitability. Previous research in this area has focused on examining the impact of jet fuel prices on airline profitability and the value of the firm (Government Accountability Office [GAO] Report, September 2014). Fuel burn is also a significant source of greenhouse gas emissions. Here again, there is literature that looks at the effect of energy prices and exchange-traded allowance units of carbon dioxide on airline profitability (Murphy, Li, Murphy, \& Cummins, 2013). Today, with concerns about global warming, regulatory pressure on airlines to evaluate alternatives and discussions about the pricing of carbon emissions, it is important to consider viable alternatives to jet fuel.

Our work investigates alternatives to jet fuel and switching from conventional jet fuel based on varying emission profiles, production costs and varying carbon prices. We use a simple decision support system to examine the link between the life cycle emissions of a range of fuels, economic costs of production and varying carbon prices. We investigate the impact of production costs and emissions from using various fuels on actual costs in a $\$ 0$ carbon price environment.

We utilize data from the Life Cycle Analysis of Emissions and cost information from traditional and alternative jet fuel sources. Then, by varying the carbon prices, we examine the actual cost of fuel. Relying on emissions from individual fuels, carbon prices and production costs, we determine that depending on the price of carbon, there may be alternative fuels that are competitively priced. In addition, producers may consider switching from conventional jet fuel to specific alternative jet fuels because of the economic advantage. Of course, while considering alternate fuels, the safe and reliable operation of the engine and aircraft are paramount.

Our contributions are in the decision-making area for fuel selection strategies for conventional and alternative jet fuels. Our findings contribute to research on decision making in the context of operations and emissions management, and provide a strategy for selecting fuel for the airline industry. Our research should provide useful information to regulators, traders, risk managers and executives of airlines as well as practitioners of sustainability management.

\section{Literature Review}

According to estimates, aviation accounts for approximately $5 \%$ of total anthropogenic radiative forcing (Note 2) (Lee et al., 2009; Dessens, Köhler, Rogers, Jones, \& Pyle, 2014). The International Civil Aviation Organization (International Civil Aviation Organization [ICAO], 2013) predicts that as air traffic increases in the future (considering a 2010 baseline), total greenhouse gas (GHG) emissions from aviation will be about $500 \%$ higher in 2050. The introduction of aviation biofuels on a large scale is paramount to carbon-neutral growth and reducing aviation GHG emissions (IATA, 2009). However, the large-scale deployment of aviation biofuels from pathways suited for aviation faces significant challenges. Examples include high production costs and the challenges of integrating aviation biofuels into regulatory regimes (Carriquiry, Du, \& Timilsina, 2011; Carter, Stratton, Bredehoeft, \& Hileman, 2011; Gegg, Budd, \& Ison, 2014), feedstock availability and scaling-up issues (U.S. Department of Energy [DOE], 2011; Seber et al., 2014), the socio-economic and environmental consequences of 
large-scale changes in land use and competition with food and feed needs (Searchinger et al., 2008; Kretschmer, Narita, \& Peterson, 2009; Serra \& Zilbermann, 2013), the amount of water associated with biomass cultivation (Scown, Horvath, \& McKone, 2011; Staples et al., 2013), and the scaling-up time required for growing biomass and building conversion facilities (Richard, 2010; Winchester, Malinab, Staples, \& Barrett, 2014).

Aviation is responsible for $2 \%$ of the world's carbon dioxide (CO2) emissions (Penner, Lister, Griggs, Dokken, \& McFarland, 1999), which has caused a great deal of concern. In November 2007, the European Parliament voted to bring aviation into the European GHG emission trading system. The legislation was scheduled to take effect in 2011, and it would have required that all airlines flying within or into Europe cut their GHG emissions by $10 \%$ or buy $\mathrm{CO}_{2}$ allowances on the open market (Roosevelt, 2007; Wald \& Kanter, 2007). Since 2012, emissions from all flights from, to and within the European Economic Area (EEA) - the 28 EU Member States, plus Iceland, Liechtenstein and Norway - have been included in the EU Emissions Trading System (EU ETS). The legislation, adopted in 2008, was intended to apply to EU and non-EU airlines alike. In order to allow time for negotiations on a global market-based measure applied to aviation emissions, the EU ETS requirements were suspended for flights in 2012 to and from non-European countries. For 2013-2016, the legislation was also amended so that only emissions from flights within the EEA fell under the EU ETS. The EU made this change following agreement by the International Civil Aviation Organization (ICAO) Assembly in October 2013 to develop a global market-based mechanism to address international aviation emissions by 2016 and apply it by 2020. In December 2007, the attorney general of the state of California (in conjunction with many other states) filed a petition with the US Environmental Protection Agency (EPA) to reduce emissions from aircrafts that contribute to global warming (Roosevelt, 2007). On July 25, 2016, the EPA issued the final endangerment finding (Note 1) under section 231(a) (2) (A) of the Clean Air Act for aviation emissions. It noted that emissions from US aircraft accounted for $12 \%$ of all US transportation greenhouse gas (GHG) emissions and $3 \%$ of total US GHG emissions (Environmental Protection Agency [EPA], 2016).

\section{Description of the Issue}

For the long-term viability of transportation fuels, they must be both economical and environmentally sustainable. Alternatives to jet fuel also diversify the sources of energy. Jet fuels from renewable resources have a different profile than conventional fuels in terms of their extraction, production and combustion. Given that they are based on renewable resources, they can potentially reduce GHG emissions from aviation (ICAO, 2009).

There has been work done in the literature on developing a methodology and tool for assessing feedstock readiness levels for converting plant-based feedstock into aviation biofuels (Steiner, Lewis, Baumes, \& Brown, 2012). There are also studies on the maturity of technological and commercial options for lignocellulosic based biomass feedstock for jet fuel (Mahwood, Gazis, Hoefnagels, \& Jong, 2015), which documents extensive variation in both the technological capabilities as well as the commercial and manufacturing capabilities of different pathways. There has also been work done in the literature on how the aviation industry should respond to the global carbon cap, especially the role of offsetting aviation emissions and carbon credits (Becken \& Mackey, 2017). Other studies have looked at how airlines should operate in a carbon-constrained world in terms of adjusting routes (Ko, Yang, \& Kim, 2017).

The focus of this paper is a comparison of GHG emissions from various alternatives to jet fuel, the associated production costs and the variations in carbon pricing in order to determine the optimal fuel selection in a carbon-constrained world. The data for each analysis come from the literature.

To determine whether there are benefits from producing and using alternative jet fuels, we consider the economic benefits of putting a price on GHG emissions. Alternatives to traditional jet fuels may hold the promise of a solution to volatile oil prices, energy security, regulatory issues and environmental issues and may also help reduce the greenhouse gas impact from aviation. In addition, utilizing an alternative fuel source could help airlines comply with regulations without paying penalties or buying carbon credits from the marketplace.

\section{Method}

\subsection{Conventional and Alternative Jet Fuels and Emission Profiles}

The metrics for comparing alternatives to jet fuels consider whether the alternative fuels can work with existing systems in the transportation infrastructure. They also consider issues related to engine operations such as the fuel's density, flash point and stability. Additional concerns revolve around whether the production process currently exists on a commercial scale, the potential for producing alternative fuels to displace petroleum-based jet fuel, the cost of producing alternate fuel and the economic viability of doing so, the life cycle of the greenhouse gas and air emissions associated with the production of these alternative fuels and the relative 
advantages of using these alternate fuels for aviation compared to other uses. Information about the life cycle of the GHG emissions for different jet fuel pathways is available in the literature. These fuel options can be considered a direct replacement for conventional jet fuel, requiring little or no modification to the existing infrastructure or aircraft (Hileman et al., 2009; Stratton, Wong, \& Hilerman, 2010).

The fuel production pathways we considered were jet fuel from conventional crude oil, jet fuel from Canadian oil sands, Fischer-Tropsch jet fuel from natural gas, coal and biomass, and jet fuel created by hydro-processing palm oil. We constructed two potential scenarios (low emissions and high emissions) for each pathway identified in the literature and computed the life cycle GHG emissions computed for each (Hileman, Katz, Mantilla, \& Fleming, 2008; Stratton et al., 2010).

\subsection{Cost Information}

As Figure 1 illustrates, jet fuel prices have historically been closely correlated to crude oil prices.

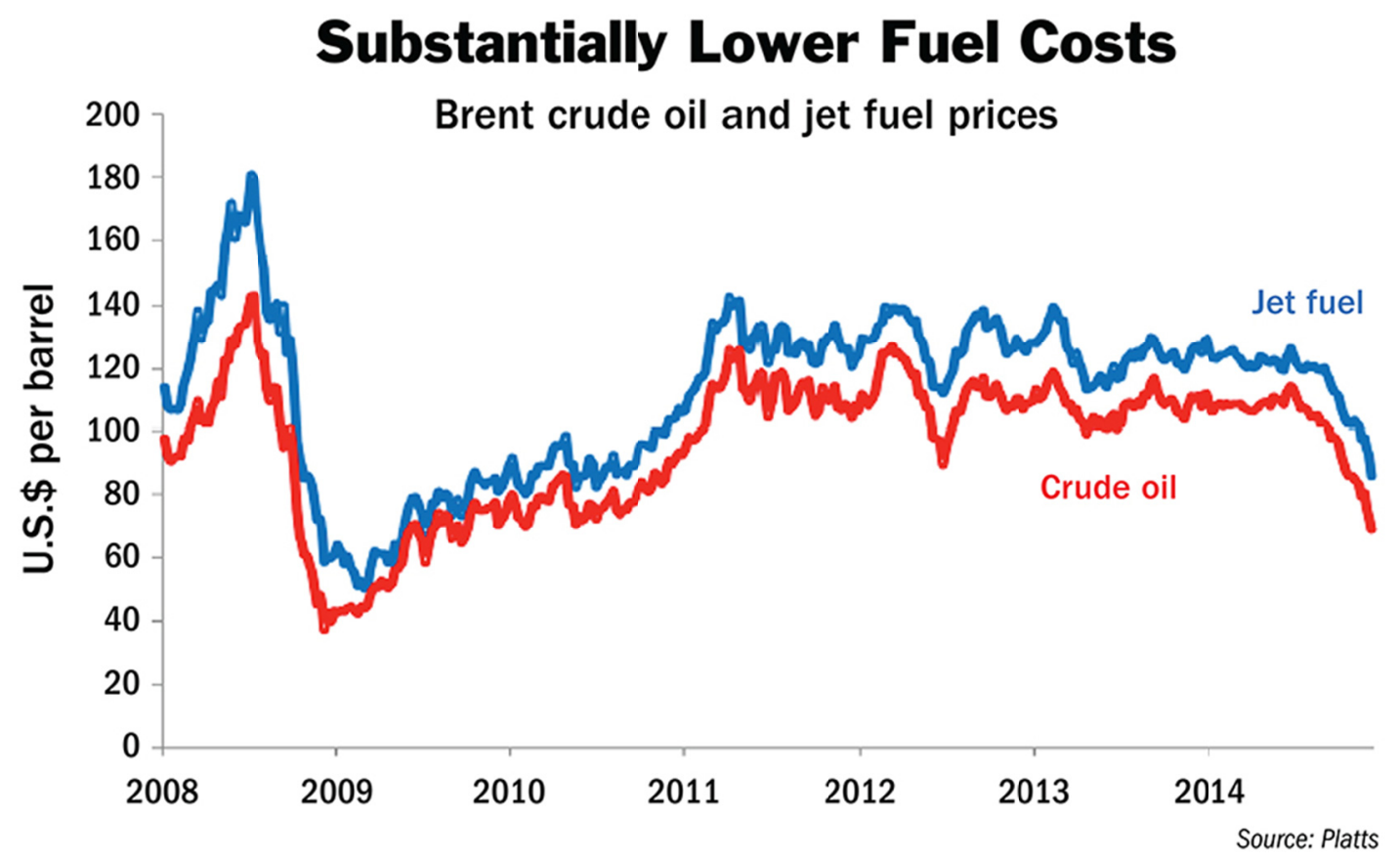

Figure 1. Jet fuel and crude oil pricing

Historically, the spot price of jet fuel rarely exceeded $\$ 1.00$ per gallon. From 2004 to 2008 the prices increased from $\$ 1.00$ per gallon to more than $\$ 4.00$ per gallon and then fell to below $\$ 1.20$ per gallon in March 2009 . Prices in 2016 fluctuated from a low of $\$ 0.93$ per gallon in January 2016 to a high of $\$ 1.49$ per gallon in December 2016. More recently prices have moved from a low of $\$ 1.30$ in June 2017 to $\$ 2.19$ in September 2018 . This price volatility has caused significant problems for the airline industry in terms of contract prices for jet fuel. The negative environmental impacts associated with aviation have put further pressure on the industry to minimize the effects associated with GHG emissions (Hileman, Stratton, \& Donohoo, 2010).

When considering alternatives to conventional petroleum-derived jet fuel in commercial aviation, price and environmental effect need to be considered. Historically, the rise in world oil prices has led to a commensurate rise in the price of jet fuel, contributing to the bankruptcy of several airlines and mergers in the industry.

As Figure 2 illustrates, jet fuel prices directly affect the profitability of airlines, evident in the sensitivities of earnings per share (EPS) of their stock. 


\title{
2015 Estimated Earnings-Per-Share Sensitivity to Changes in Jet Fuel
}

\begin{tabular}{|r|r|r|r|r|r|r|}
\multicolumn{7}{c|}{ AIRLINES } \\
\hline$\$ 3.15$ & $\$ 3.34$ & $\$ 3.46$ & $\$ 3.58$ & $\$ 0.72$ & $\$ 1.86$ & $\$ 1.43$ \\
\hline 3.05 & 3.94 & 3.68 & 3.81 & 0.83 & 2.00 & 2.39 \\
\hline 2.95 & 4.55 & 3.90 & 4.04 & 0.95 & 2.15 & 3.34 \\
\hline 2.85 & 5.16 & 4.13 & 4.27 & 1.06 & 2.30 & 4.30 \\
\hline 2.75 & 5.76 & 4.35 & 4.49 & 1.18 & 2.44 & 5.25 \\
\hline 2.65 & 6.37 & 4.57 & 4.72 & 1.29 & 2.59 & 6.21 \\
\hline 2.55 & 6.98 & 4.80 & 4.95 & 1.41 & 2.74 & 7.13 \\
\hline 2.45 & 7.58 & 5.02 & 5.17 & 1.52 & 2.88 & 8.04 \\
\hline 2.35 & 8.19 & 5.25 & 5.40 & 1.64 & 3.03 & 8.96 \\
\hline 2.25 & 8.80 & 5.47 & 5.63 & 1.75 & 3.18 & 9.87 \\
\hline 2.15 & 9.40 & 5.69 & 5.86 & 1.87 & 3.32 & 10.78 \\
\hline 2.05 & 10.01 & 5.92 & 6.08 & 1.98 & 3.47 & 11.69 \\
\hline 1.95 & 10.62 & 6.14 & 6.31 & 2.10 & 3.62 & 12.61 \\
\hline 1.85 & 11.22 & 6.34 & 6.54 & 2.21 & 3.76 & 13.52 \\
\hline 1.75 & 11.83 & 6.59 & 6.76 & 2.33 & 3.91 & 14.43 \\
\hline 1.65 & 12.44 & 6.81 & 6.99 & 2.44 & 4.06 & 15.34 \\
\hline 1.55 & 13.04 & 7.04 & 7.22 & 2.55 & 4.20 & 16.26 \\
\hline
\end{tabular}

* Shaded sections broadly compare to published forecasts

Source: J.P. Morgan estimates

Figure 2. Jet fuel prices and airline profitability

\begin{abstract}
The cost structure of several alternative jet fuels is available in the literature and considered in this analysis. These include jet fuel derived (1) from conventional petroleum, (2) from oil sands, (3) synthetically from natural gas, (4) from coal using the Fischer-Tropsch (FT) process and carbon capture and storage (CCS), (5) combinations of coal and biomass via the FT process and CCS, and (6) renewable oils.

\subsection{Market Mechanism for Aviation and Carbon Trading}

Since the Paris Climate Change Conference in December 2015, there have been increasing efforts to put a price on carbon emissions around the world. There has been a threefold increase over the last decade in the share of emissions covered by carbon pricing. About 7 gigatons of carbon dioxide equivalent $\left(\mathrm{GtCO}_{2} \mathrm{e}\right)$ or about $12 \%$ of global emissions are covered by carbon pricing instruments, accounting for $50 \%$ emissions in these jurisdictions and valued at US $\$ 50$ billion. The majority of emissions (85\%) are priced at less than US $\$ 10$ per $\mathrm{tCO}_{2} \mathrm{e}$, which is lower than the price that economic models have estimated is needed to meet the $2^{\circ} \mathrm{C}$ climate stabilization goal recommended by scientists and the 2015 Paris Agreement (World Bank, 2015). As Figure 3 indicates, the price of carbon allowances has tripled in the EUETS, from a low of $€ 4.38$ per ton in May 2017 to $€ 13.82$ per ton in April 2018, making them the world's best performing energy commodity. In July 2019 the price of carbon
\end{abstract}


allowances reached a high of $€ 29.00$ per ton (Markets Insider, 2019).

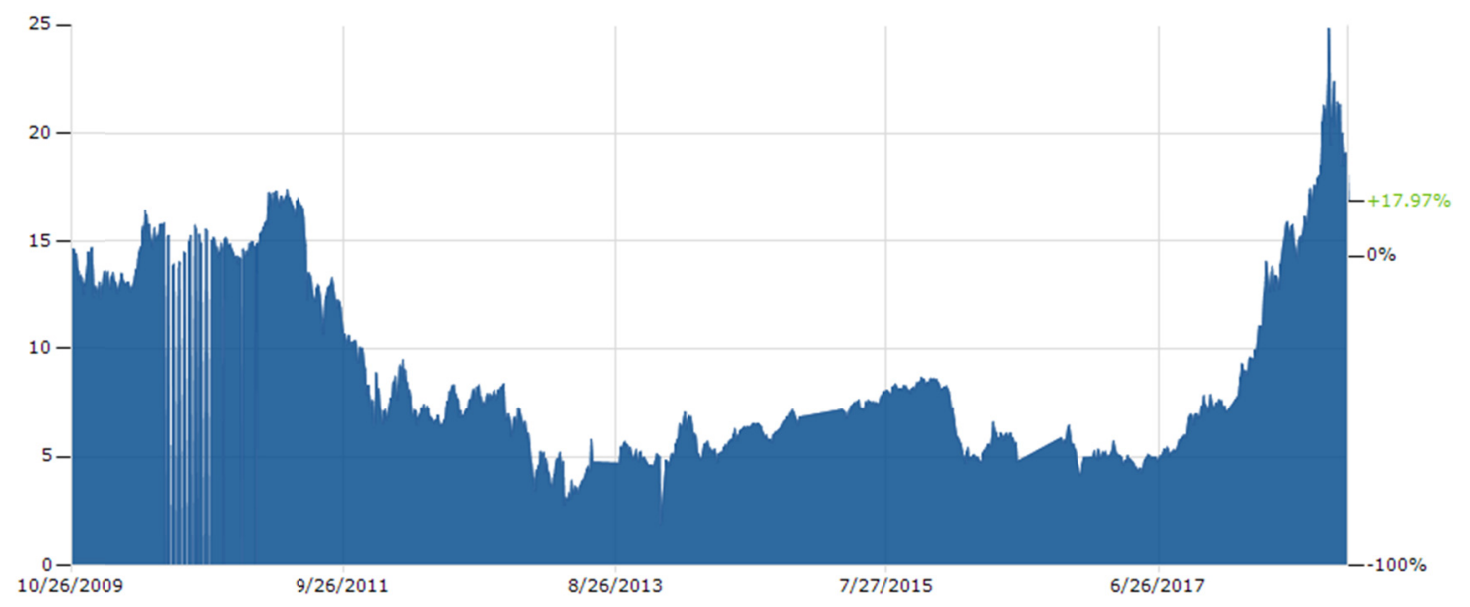

Figure 3. Carbon pricing (Eur) in the EUETS

Source: https://markets.businessinsider.com/commodities/co2-emissionsrechte

Firms use carbon pricing as a tool to analyze businesses, investments, and risk management strategies as well as to identify revenue opportunities and cost savings (World Bank, 2015). With the International Civil Aviation Organization's (ICAO) goal to cap net carbon emissions at 2020 levels, significant work is underway in the aviation industry in this regard (World Bank, 2015).

As described above, the use of alternative fuels and a market-based mechanism of carbon pricing and trading are important elements in meeting targets for the aviation industry. Thus, depending on the specific prices of carbon, we posit that the industry would consider using the most optimal fuel to ensure viable operations.

\section{Data}

Table 1 displays the GHG emissions through the entire life-cycle of jet fuel production from the well, field, or mine to the production facility, processing of these materials into fuels, the transportation and distribution of the fuel to the aircraft tank, and finally, the combustion of the fuel in the aircraft (Stratton et al., 2010). These GHG well-to-wake (WTW) (Note 3) emissions are outlined below for a variety of fuels.

Table 1. Emission profiles for conventional jet fuel and alternative jet fuels

\begin{tabular}{lll}
\hline & Total WTW GHG Emissions $\left(\mathrm{gCO}_{2} \mathrm{e} / \mathrm{MJ}\right)$ & $\mathrm{GHG}$ emissions (tons/boe) \\
Jet Fuel & 87.5 & 0.565 \\
Oil Sands & 103.4 & 0.668 \\
FT Natural Gas & 101 & 0.652 \\
FT Coal w/CCS & 97.2 & 0.628 \\
FT (Coal + Biomass) with CCS & 2.8 & 0.018 \\
Palm Oil to HRJ with no land use & 30.1 & 0.194 \\
\hline
\end{tabular}

Table 2 provides the cost for fuels in 2017 (Hileman et al., 2009). The costs are reflected as a range - base low indicates the lower end of the range and base high reflects the costs at the higher end of the range, as detailed in the cost information section.

Table 2. Cost range for conventional jet fuel and alternative jet fuels

\begin{tabular}{lll}
\hline & 2017 Base Low Cost $(\$ /$ gal $)$ & 2017 Base High Cost (\$/gal) \\
\hline Jet Fuel & $\$ 1.20$ & $\$ 2.57$ \\
Oil Sands & $\$ 1.19$ & $\$ 1.55$ \\
FT Natural Gas & $\$ 1.40$ & $\$ 2.50$ \\
FT Coal w/CCS & $\$ 1.60$ & $\$ 1.92$ \\
FT (Coal + Biomass) with CCS & $\$ 1.97$ & $\$ 2.39$ \\
Palm Oil to HRJ with no land use & $\$ 2.12$ & $\$ 2.78$ \\
\hline
\end{tabular}


While Table 1 lists the GHG emissions from a variety of fuels (Stratton et al., 2010), Table 2 provides the cost for fuels (Hileman et al., 2009), and a wide range in carbon pricing as outlined historically (World Bank, 2015; Markets Insider, 2019) is considered.

\section{Development of the Decision Support System Model}

We developed a simulation (.xls and VBA model) to test a model of fuel production costs coupled with life cycle greenhouse gas emissions for conventional jet fuel and alternatives to traditional jet fuel. The model included consideration of the cost of environmental regulations, as reflected in GHG prices in a carbon-constrained world, in order to obtain the true cost of fuel.

The actual low-price situation takes the base low cost of the fuel and adds the carbon cost based on the emission profile of the fuel and the cost of GHGs. The actual high price situation takes the base high cost of the fuel and adds the carbon cost based on the emission profile of the fuel and the cost of GHGs. This simulation allows for different costs of GHG to be considered and emission costs to be included as part of the fuel costs to allow for optimal fuel selection.

We considered four different scenarios for GHG pricing:

1) No charge for greenhouse gas emissions, meaning the GHG price is $\$ 0 /$ ton

2) GHG price is $\$ 5 /$ ton

3) GHG price is $\$ 50 /$ ton

4) GHG price is $\$ 100 /$ ton

Table 3. Actual price of fuel at $\$ 0 /$ ton for GHG

\begin{tabular}{|c|c|c|c|c|c|c|c|c|c|}
\hline & $\begin{array}{l}\text { Total WTW } \\
\text { GHG } \\
\text { Emissions } \\
\text { (gCO2e/MJ) }\end{array}$ & $\begin{array}{l}\text { GHG } \\
\text { emissions } \\
\text { (ton/boe) }\end{array}$ & $\begin{array}{l}\text { GHG } \\
\text { prices } \\
(\$ / \text { ton })\end{array}$ & $\begin{array}{l}\text { GHG } \\
\text { costs in } \\
\$ / \text { barrel }\end{array}$ & $\begin{array}{l}\text { GHG } \\
\text { costs } \\
\text { in } \\
\$ / \text { gal }\end{array}$ & $\begin{array}{l}2017 \\
\text { Base } \\
\text { Low } \\
\text { Cost } \\
(\$ / \text { gal }) \\
\end{array}$ & $\begin{array}{l}2017 \\
\text { Base } \\
\text { High } \\
\text { Cost } \\
(\$ / \text { gal }) \\
\end{array}$ & $\begin{array}{l}2017 \\
\text { Actual Low } \\
\text { Price } \\
\text { Situation } \\
(\$ / \text { gal) } \\
\end{array}$ & $\begin{array}{l}2017 \\
\text { Actual } \\
\text { High Price } \\
\text { Situation } \\
(\$ / \text { gal }) \\
\end{array}$ \\
\hline Jet Fuel & 87.5 & 0.565 & & $\$ 0.00$ & $\$ 0.00$ & $\$ 1.20$ & $\$ 2.57$ & $\$ 1.20$ & $\$ 2.57$ \\
\hline Oil Sands & 103.4 & 0.668 & & $\$ 0.00$ & $\$ 0.00$ & $\$ 1.19$ & $\$ 1.55$ & $\$ 1.19$ & $\$ 1.55$ \\
\hline FT NG & 101 & 0.652 & & $\$ 0.00$ & $\$ 0.00$ & $\$ 1.40$ & $\$ 2.50$ & $\$ 1.40$ & $\$ 2.50$ \\
\hline FT Coal w/CCS & 97.2 & 0.628 & & $\$ 0.00$ & $\$ 0.00$ & $\$ 1.60$ & $\$ 1.92$ & $\$ 1.60$ & $\$ 1.92$ \\
\hline $\begin{array}{l}\text { FT (Coal + Biomass) } \\
\text { with CCS }\end{array}$ & 2.8 & 0.018 & & $\$ 0.00$ & $\$ 0.00$ & $\$ 1.97$ & $\$ 2.39$ & $\$ 1.97$ & $\$ 2.39$ \\
\hline $\begin{array}{l}\text { Palm Oil to HRJ with } \\
\text { no land use }\end{array}$ & 30.1 & 0.194 & & $\$ 0.00$ & $\$ 0.00$ & $\$ 2.12$ & $\$ 2.78$ & $\$ 2.12$ & $\$ 2.78$ \\
\hline
\end{tabular}

Table 4. Actual price of fuel at $\$ 5 /$ ton for GHG

\begin{tabular}{|c|c|c|c|c|c|c|c|c|c|}
\hline & $\begin{array}{l}\text { Total WTW } \\
\text { GHG } \\
\text { Emissions } \\
(\mathrm{gCO} 2 \mathrm{e} / \mathrm{MJ})\end{array}$ & $\begin{array}{l}\text { GHG } \\
\text { emissions } \\
\text { (ton/boe) }\end{array}$ & $\begin{array}{l}\text { GHG } \\
\text { prices } \\
\text { (\$/ton) }\end{array}$ & $\begin{array}{l}\text { GHG } \\
\text { costs in } \\
\$ / \text { barrel }\end{array}$ & $\begin{array}{l}\text { GHG } \\
\text { costs } \\
\text { in } \\
\$ / \text { gal }\end{array}$ & $\begin{array}{l}2017 \\
\text { Base } \\
\text { Low } \\
\text { Cost } \\
(\$ / \text { gal) } \\
\end{array}$ & $\begin{array}{l}2017 \\
\text { Base } \\
\text { High } \\
\text { Cost } \\
(\$ / \text { gal }) \\
\end{array}$ & $\begin{array}{l}2017 \\
\text { Actual Low } \\
\text { Price } \\
\text { Situation } \\
\text { (\$/gal) }\end{array}$ & $\begin{array}{l}2017 \\
\text { Actual } \\
\text { High Price } \\
\text { Situation } \\
(\$ / \text { gal }) \\
\end{array}$ \\
\hline Jet Fuel & 87.5 & 0.565 & $\$ 5.00$ & $\$ 2.83$ & $\$ 0.07$ & $\$ 1.20$ & $\$ 2.57$ & $\$ 1.267$ & $\$ 2.637$ \\
\hline Oil Sands & 103.4 & 0.668 & $\$ 5.00$ & $\$ 3.34$ & $\$ 0.08$ & $\$ 1.19$ & $\$ 1.55$ & $\$ 1.269$ & $\$ 1.629$ \\
\hline FT NG & 101 & 0.652 & $\$ 5.00$ & $\$ 3.26$ & $\$ 0.08$ & $\$ 1.40$ & $\$ 2.50$ & $\$ 1.477$ & $\$ 2.577$ \\
\hline FT Coal w/CCS & 97.2 & 0.628 & $\$ 5.00$ & $\$ 3.14$ & $\$ 0.07$ & $\$ 1.60$ & $\$ 1.92$ & $\$ 1.674$ & $\$ 1.994$ \\
\hline $\begin{array}{l}\text { FT (Coal + Biomass) } \\
\text { with CCS }\end{array}$ & 2.8 & 0.018 & $\$ 5.00$ & $\$ 0.09$ & $\$ 0.00$ & $\$ 1.97$ & $\$ 2.39$ & $\$ 1.972$ & $\$ 2.392$ \\
\hline $\begin{array}{l}\text { Palm Oil to HRJ with } \\
\text { no land use }\end{array}$ & 30.1 & 0.194 & $\$ 5.00$ & $\$ 0.97$ & $\$ 0.02$ & $\$ 2.12$ & $\$ 2.78$ & $\$ 2.143$ & $\$ 2.803$ \\
\hline
\end{tabular}


Table 5. Actual price of fuel at $\$ 50 /$ ton for $\mathrm{GHG}$

\begin{tabular}{|c|c|c|c|c|c|c|c|c|c|}
\hline & $\begin{array}{l}\text { Total WTW } \\
\text { GHG } \\
\text { Emissions } \\
(\mathrm{gCO} 2 \mathrm{e} / \mathrm{MJ})\end{array}$ & $\begin{array}{l}\text { GHG } \\
\text { emissions } \\
\text { (ton/boe) }\end{array}$ & $\begin{array}{l}\text { GHG } \\
\text { prices } \\
\text { (\$/ton) }\end{array}$ & $\begin{array}{l}\text { GHG } \\
\text { costs in } \\
\text { \$/barrel }\end{array}$ & $\begin{array}{l}\text { GHG } \\
\text { costs } \\
\text { in } \\
\$ / \text { gal }\end{array}$ & $\begin{array}{l}2017 \\
\text { Base } \\
\text { Low } \\
\text { Cost } \\
\text { (\$/gal) }\end{array}$ & $\begin{array}{l}2017 \\
\text { Base } \\
\text { High } \\
\text { Cost } \\
(\$ / \text { gal }) \\
\end{array}$ & $\begin{array}{l}2017 \\
\text { Actual Low } \\
\text { Price } \\
\text { Situation } \\
(\$ / \text { gal) }\end{array}$ & $\begin{array}{l}2017 \\
\text { Actual } \\
\text { High Price } \\
\text { Situation } \\
(\$ / \text { gal }) \\
\end{array}$ \\
\hline Jet Fuel & 87.5 & 0.565 & $\$ 50.00$ & $\$ 28.27$ & $\$ 0.67$ & $\$ 1.20$ & $\$ 2.57$ & $\$ 1.87$ & $\$ 3.24$ \\
\hline Oil Sands & 103.4 & 0.668 & $\$ 50.00$ & $\$ 33.40$ & $\$ 0.80$ & $\$ 1.19$ & $\$ 1.55$ & $\$ 1.98$ & $\$ 2.34$ \\
\hline FT NG & 101 & 0.652 & $\$ 50.00$ & $\$ 32.63$ & $\$ 0.78$ & $\$ 1.40$ & $\$ 2.50$ & $\$ 2.17$ & $\$ 3.27$ \\
\hline FT Coal w/CCS & 97.2 & 0.628 & $\$ 50.00$ & $\$ 31.40$ & $\$ 0.75$ & $\$ 1.60$ & $\$ 1.92$ & $\$ 2.34$ & $\$ 2.66$ \\
\hline $\begin{array}{l}\text { FT (Coal + Biomass) } \\
\text { with CCS }\end{array}$ & 2.8 & 0.018 & $\$ 50.00$ & $\$ 0.90$ & $\$ 0.02$ & $\$ 1.97$ & $\$ 2.39$ & $\$ 1.99$ & $\$ 2.41$ \\
\hline $\begin{array}{l}\text { Palm Oil to HRJ with } \\
\text { no land use }\end{array}$ & 30.1 & 0.194 & $\$ 50.00$ & $\$ 9.72$ & $\$ 0.23$ & $\$ 2.12$ & $\$ 2.78$ & $\$ 2.3515$ & $\$ 3.01$ \\
\hline
\end{tabular}

Table 6. Actual price of fuel at $\$ 100 /$ ton for GHG

\begin{tabular}{|c|c|c|c|c|c|c|c|c|c|}
\hline & $\begin{array}{l}\text { Total WTW } \\
\text { GHG } \\
\text { Emissions } \\
(\mathrm{gCO} 2 \mathrm{e} / \mathrm{MJ})\end{array}$ & $\begin{array}{l}\text { GHG } \\
\text { emissions } \\
\text { (ton/boe) }\end{array}$ & $\begin{array}{l}\text { GHG } \\
\text { prices } \\
\text { (\$/ton) }\end{array}$ & $\begin{array}{l}\text { GHG } \\
\text { costs in } \\
\text { \$/barrel }\end{array}$ & $\begin{array}{l}\text { GHG } \\
\text { costs } \\
\text { in } \\
\$ / \text { gal }\end{array}$ & $\begin{array}{l}2017 \\
\text { Base } \\
\text { Low } \\
\text { Cost } \\
(\$ / \text { gal }) \\
\end{array}$ & $\begin{array}{l}2017 \\
\text { Base } \\
\text { High } \\
\text { Cost } \\
\text { (\$/gal) } \\
\end{array}$ & $\begin{array}{l}2017 \\
\text { Actual Low } \\
\text { Price } \\
\text { Situation } \\
\text { (\$/gal) } \\
\end{array}$ & $\begin{array}{l}2017 \\
\text { Actual } \\
\text { High Price } \\
\text { Situation } \\
(\$ / \text { gal }) \\
\end{array}$ \\
\hline Jet Fuel & 87.5 & 0.565 & $\$ 100.00$ & $\$ 56.54$ & $\$ 1.35$ & $\$ 1.20$ & $\$ 2.57$ & $\$ 2.54$ & $\$ 3.91$ \\
\hline Oil Sands & 103.4 & 0.668 & $\$ 100.00$ & $\$ 66.81$ & $\$ 1.59$ & $\$ 1.19$ & $\$ 1.55$ & $\$ 2.78$ & $\$ 3.14$ \\
\hline FT NG & 101 & 0.652 & $\$ 100.00$ & $\$ 65.26$ & $\$ 1.55$ & $\$ 1.40$ & $\$ 2.50$ & $\$ 2.95$ & $\$ 4.05$ \\
\hline FT Coal w/CCS & 97.2 & 0.628 & $\$ 100.00$ & $\$ 62.80$ & $\$ 1.50$ & $\$ 1.60$ & $\$ 1.92$ & $\$ 3.09$ & $\$ 3.41$ \\
\hline $\begin{array}{l}\text { FT (Coal + Biomass) } \\
\text { with CCS }\end{array}$ & 2.8 & 0.018 & $\$ 100.00$ & $\$ 1.81$ & $\$ 0.04$ & $\$ 1.97$ & $\$ 2.39$ & $\$ 2.01$ & $\$ 2.43$ \\
\hline $\begin{array}{l}\text { Palm Oil to HRJ with } \\
\text { no land use }\end{array}$ & 30.1 & 0.194 & $\$ 100.00$ & $\$ 19.45$ & $\$ 0.46$ & $\$ 2.12$ & $\$ 2.78$ & $\$ 2.58$ & $\$ 3.24$ \\
\hline
\end{tabular}

\section{Results}

Figures 4-7 illustrate the results for the four different scenarios of the actual cost of fuel at varying GHG prices. Figures 8 and 9 depict the actual low and high price situations for a range of GHG prices from $\$ 0 /$ ton to $\$ 250 /$ ton.

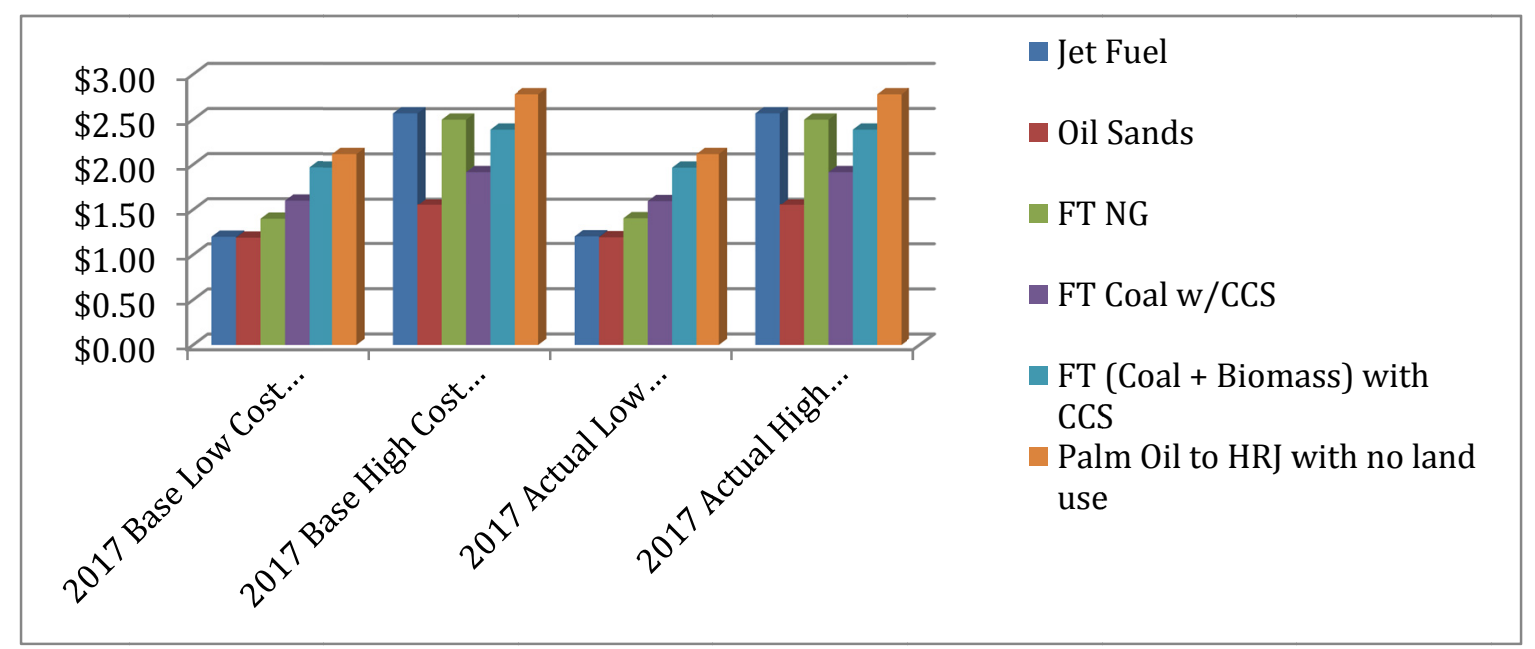

Figure 4. Comparison of base and actual cost of fuel when GHG price is $\$ 0 /$ ton 


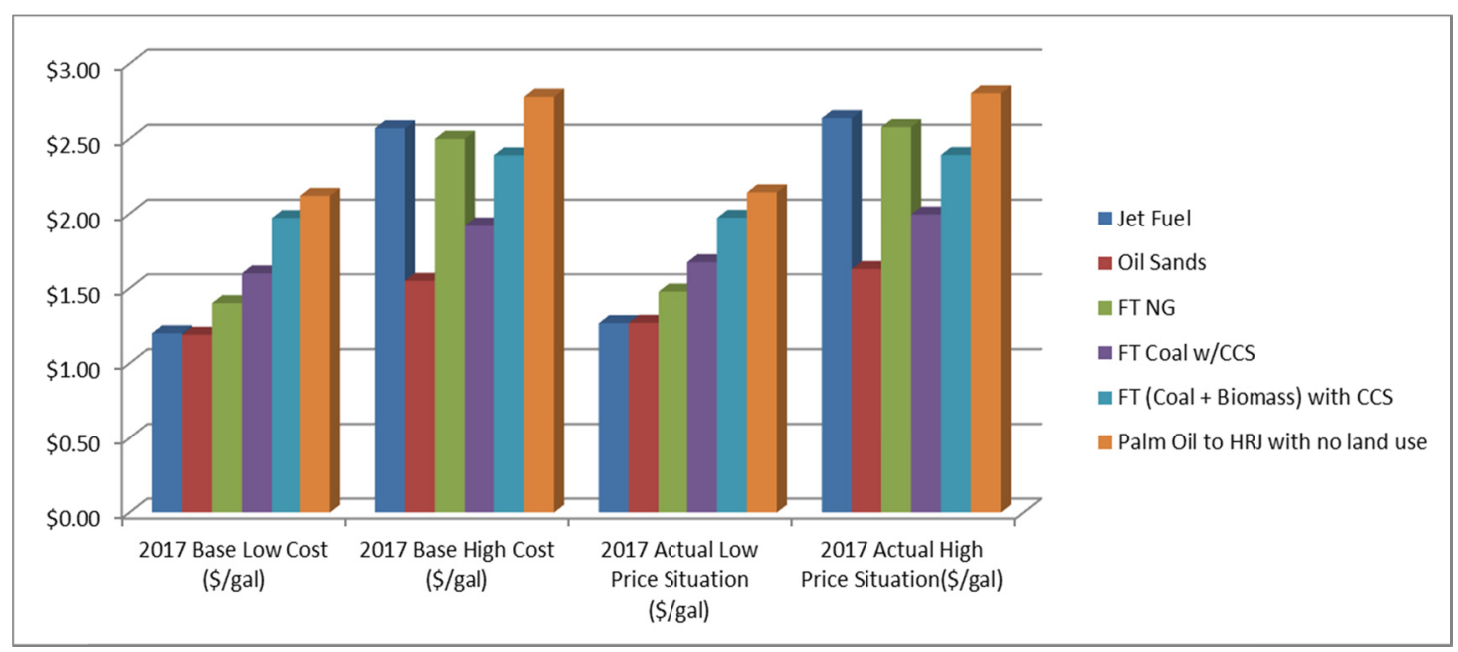

Figure 5. Comparison base and actual cost of fuel when GHG price is $\$ 5 /$ ton

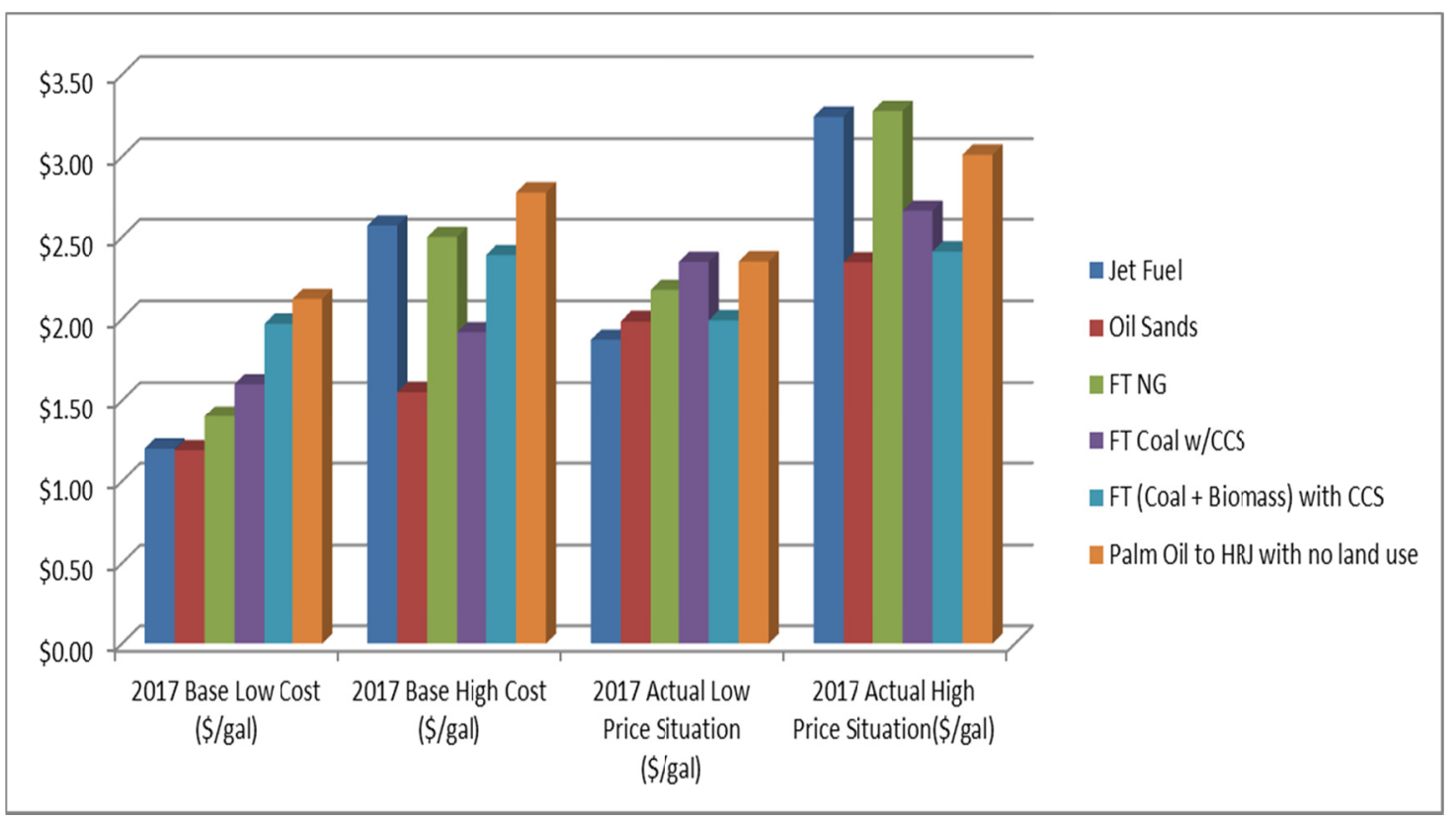

Figure 6. Comparison base and actual cost of fuel when GHG price is $\$ 50 /$ ton 


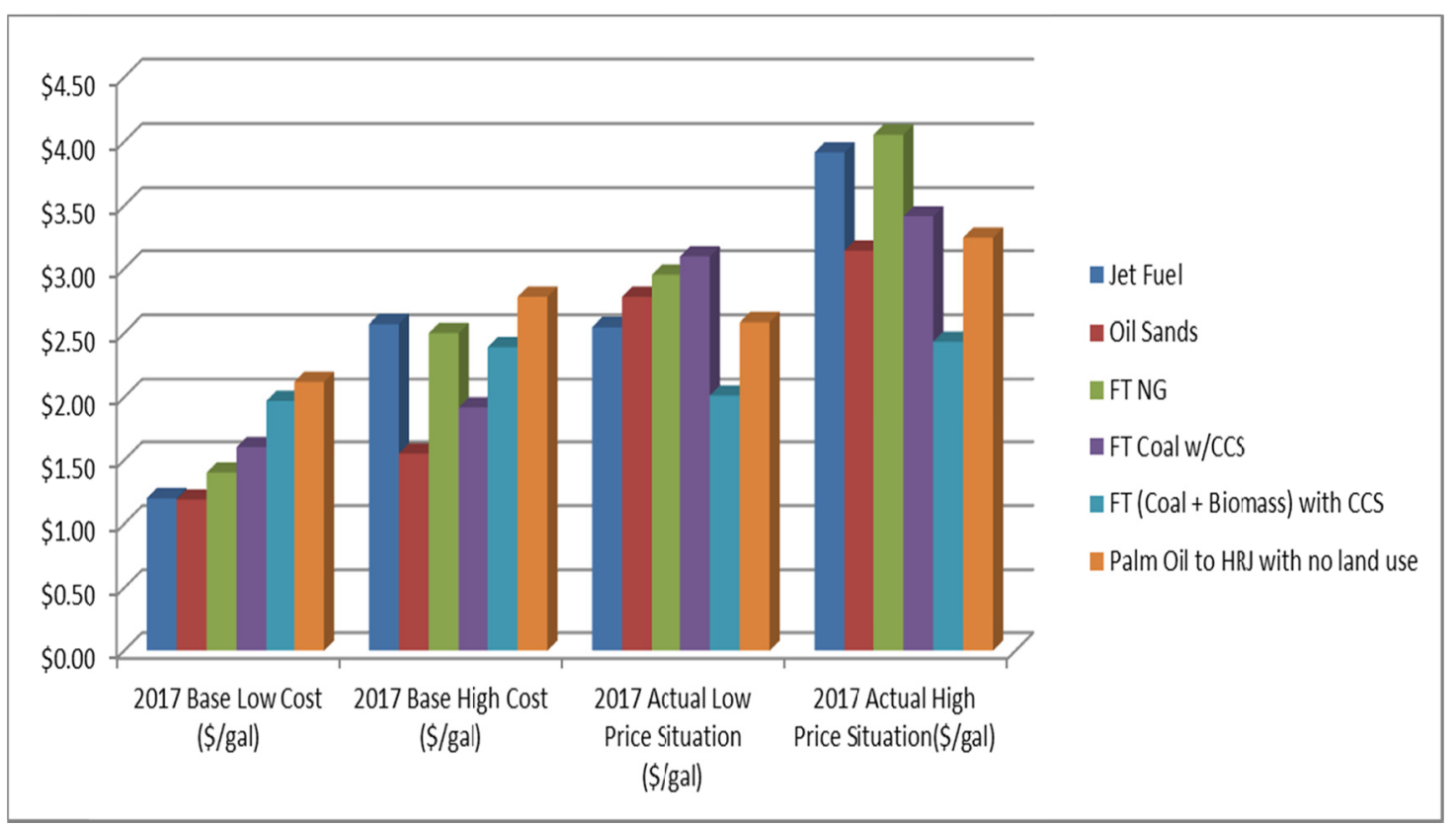

Figure 7. Comparison base and actual cost of fuel when GHG price is $\$ 100 /$ ton

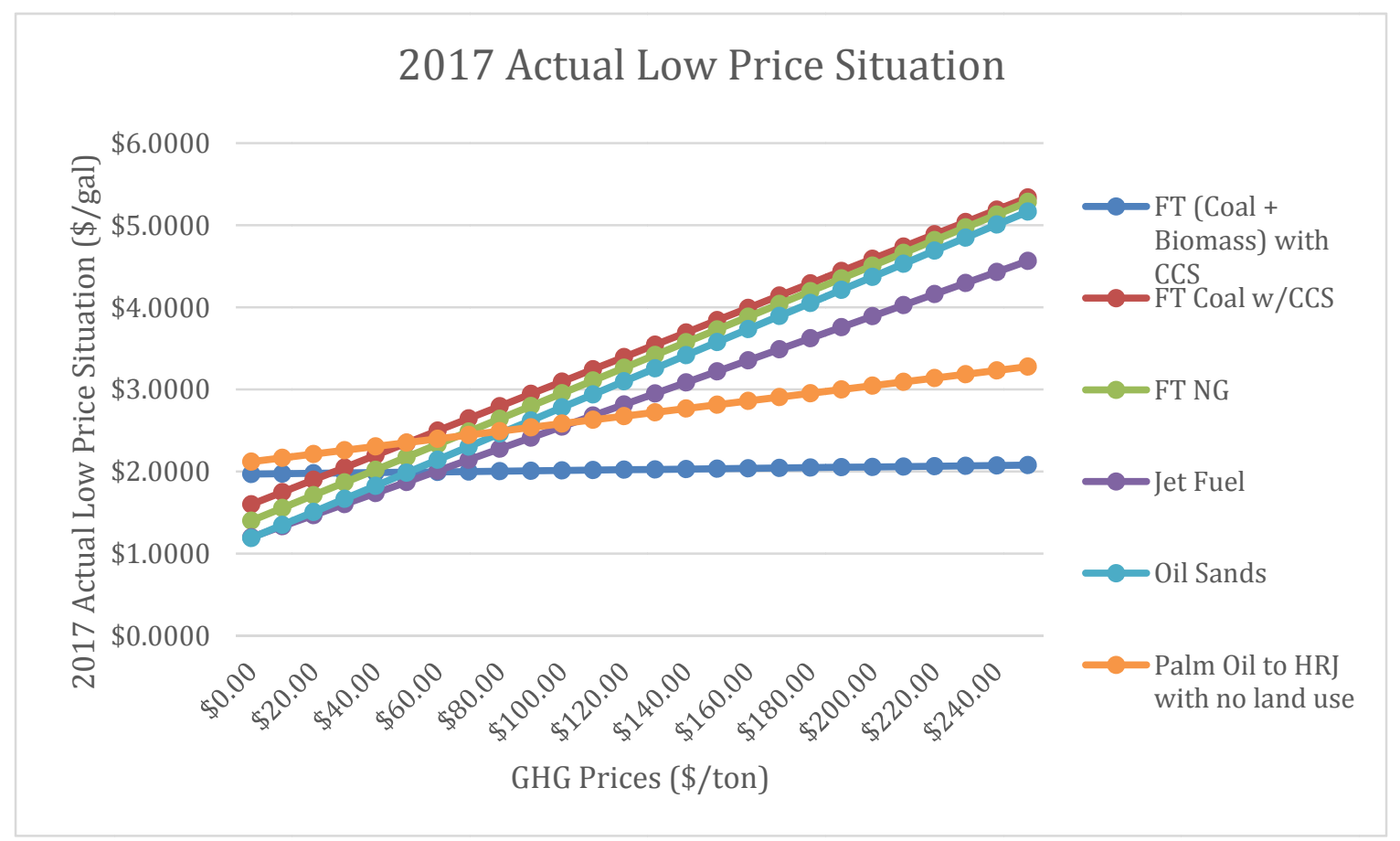

Figure 8. Actual low price situation for a range of GHG prices from $\$ 0 /$ ton to $\$ 250 /$ ton 


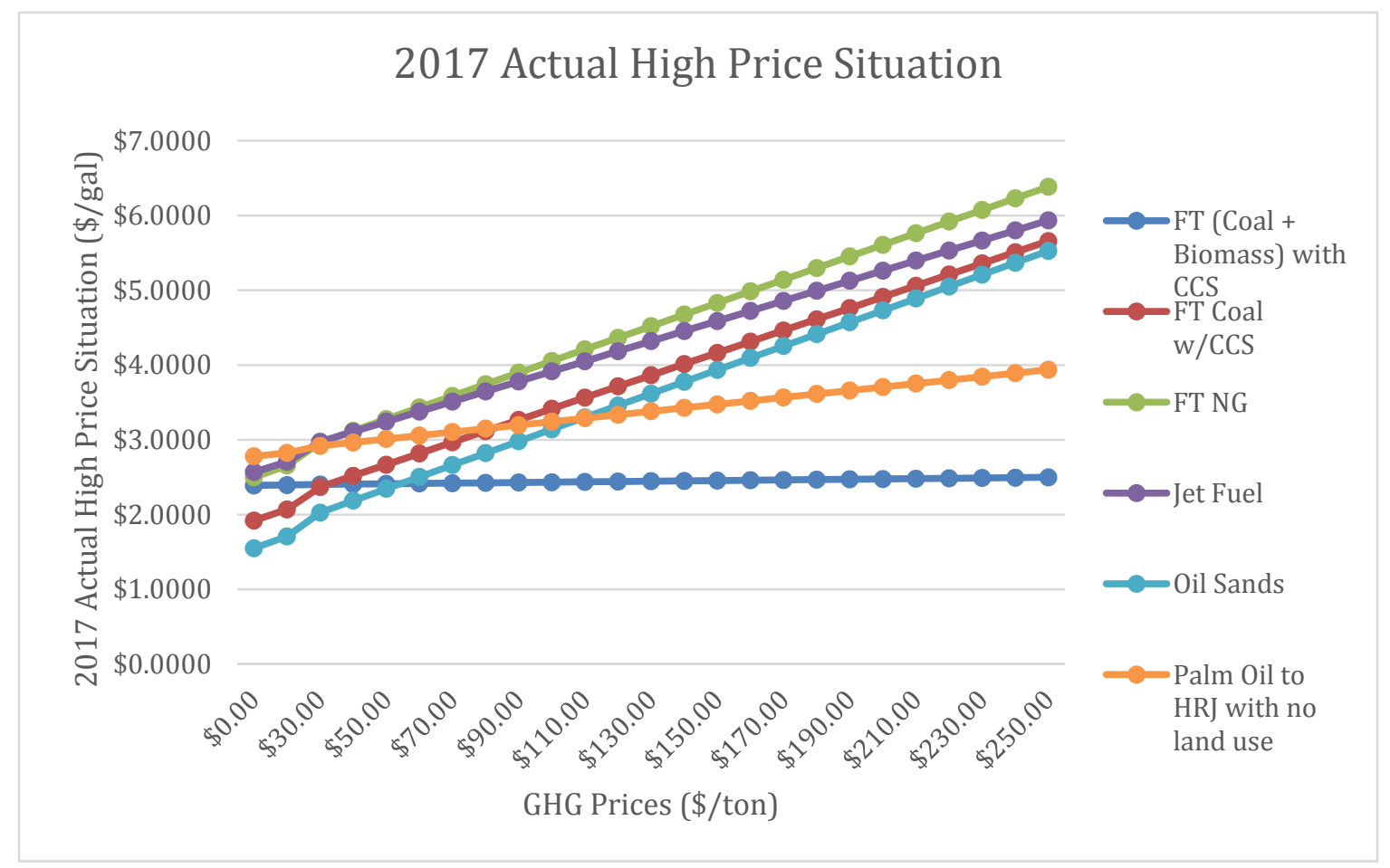

Figure 9. Actual high price situation for a range of $\mathrm{GHG}$ prices from $\$ 0 /$ ton to $\$ 250 /$ ton

\section{Conclusions and Recommendations}

As the results indicate, it seems clear that there is a place for sustainable alternatives to traditional jet fuel in aviation. While traditional jet fuel is the preferred fuel of choice when oil prices are low, the situation changes when GHG prices hit \$70/ton. At this GHG price, Fischer Tropsch (Coal + Biomass) with CCS becomes the preferred choice of fuel. Similarly, when oil prices are high, oil sands are the preferred fuel of choice. However, when GHG prices hit $\$ 80 /$ ton, oil sands are no longer the preferred fuel. At this GHG price, Fischer Tropsch (Coal + Biomass) with CCS becomes the preferred choice of fuel.

While we have made contributions in the area, the study is not without limitations. While fuel selection is important, when evaluating a switch from conventional to alternate sources of jet fuel other considerations are of concern as well. Examples include the practical ramifications of supply chain issues, operational issues and infrastructure issues. All of the alternate fuels we studied can be made compatible with the current infrastructure. From a commercial standpoint, currently only jet fuel made from oil sands has the potential for large-scale production, depending on oil prices. There continue to be uncertainties related to FT fuels including technology and regulatory issues that affect production costs, as well as the technology for capturing carbon dioxide and regulatory issues around its sequestration. Additionally, for FT based fuels there may be feedstock supply or pricing challenges from competing needs for automotive fuel or energy production. For palm oil based HRJ, there are land use and feedstock supply issues affecting the selection of this source for aviation fuel, in addition to the food vs. energy debate. While it is clear that in the age of climate change, we need to seek alternatives to jet fuel derived from crude oil, researchers must investigate the above-mentioned issues in greater detail, providing opportunities for future research on this topic.

\section{Acknowledgments}

The authors would like to thank Roy Matthen, Moyassar Eltigani, and Joyce Lu for their help with this project.

\section{References}

Aviation Week. (2015). Drop in Oil Prices Means an Airline Profitability Boost Now, But... Retrieved August 31, 2015

http://aviationweek.com/commercial-aviation/drop-oil-prices-means-airline-profitability-boost-now

Becken, S., \& Mackey, B. (2017). What role for offsetting aviation greenhouse gas emissions in a deep-carbon cut world? Journal of Air Transport Management, 63, 71-83. 
https://doi.org/10.1016/j.jairtraman.2017.05.009

Carriquiry, M. A., Du, X., \& Timilsina, G. R. (2011). Second generation biofuels: Economics and policies. Energy Policy, 39, 4222-4234. https://doi.org/10.1016/j.enpol.2011.04.036

Carter, N., Stratton, R., Bredehoeft, M., \& Hileman, J. (2011). Energy and environmental viability of select alternative jet fuel pathways. 47th AIAA Joint Propulsion Conference, San Diego, CA. https://doi.org/10.2514/6.2011-5968

Center for Aviation. (2018). Airline margins: Squeeze is on as Brent Crude Oil touches USD 80. Retrieved August 8, 2019 from https://centreforaviation.com/analysis/reports/airline-margins-squeeze-is-on-as-brent-crude-oil-touches-usd $80-418754$

Dessens, O., Köhler, M. O., Rogers, H. L., Jones, R. L., \& Pyle, J. A. (2014). Aviation and climate change. Transport Policy, 34, 14-20. https://doi.org/10.1016/j.tranpol.2014.02.014

EPA. (2016). EPA Finalizes First Steps to Address Greenhouse Gas Emissions from Aircraft Engines. Retrieved September 2, 2019 from https://nepis.epa.gov/Exe/ZyPDF.cgi/P100P1UN.PDF?Dockey=P100P1UN.PDF

GAO (Government Accountability Office). (2013).

Gegg, P., Budd, L., \& Ison, S. (2014). The market development of aviation biofuel: Drivers and constraints. Journal of Air Transport Management, 39, 34-40. https://doi.org/10.1016/j.jairtraman.2014.03.003

Hileman, J. I., Katz, J. B., Mantilla, J., \& Fleming, G. (2008). Payload Fuel Energy Efficiency as a Metric for Aviation Environmental Performance. Proceedings of the 26th International Congress of the Aeronautical Sciences, Anchorage, Alaska.

Hileman, J. I., Ortiz, D. S., Bartis, J. T., Wong, H. M., Donohoo, P. E., Weiss, M. A., \& Waitz, I. A. (2009). Near Term Feasibility of Alternate Jet Fuels. Massachusetts Institute of Technology and RAND Corporation, Santa Moncia, CA.

Hileman, J. I., Stratton, R. W., \& Donohoo, P. (2010). Energy Content and Alternative Jet Fuel Viability. Journal of Propulsion and Power, 26, 1184-1194 https://doi.org/10.2514/1.46232

IATA (International Air Transport Association). (2009). A global approach to reducing aviation emissions. Retrieved February 8, from http://www.iata.org/SiteCollectionDocuments/Documents/Global_Approach_Reducing_Emissions_251109 web.pdf

IATA (International Air Transport Association). (2015). Airlines continue to improve profitability. Retrieved December 2, 2016 from http://www.iata.org/pressroom/pr/Pages/2015-12-10-01.aspx

IATA (International Air Transport Association). (2016). Industry Profitability Improves. Retrieved December 2, 2016 from http://www.iata.org/pressroom/pr/Pages/2016-06-02-02.aspx

IATA (International Air Transport Association). (2019). Slowing Demand and Rising Costs Squeeze Airline Profits. Retrieved September 9, 2019, from https://www.iata.org/pressroom/pr/Pages/2019-06-02-01.aspx

ICAO (International Civil Aviation Organization). (2009). Working Paper. Conference on Aviation and Alternative Fuels, Brazil.

ICAO (International Civil Aviation Organization). (2013). Environmental report. Destination Green, Montreal.

Ko, Y. D., Jang, Y. J., \& Kim, D. Y. (2017). Strategic airline operation considering the carbon constrained air transport industry. Journal of Air Transport Management, 62, 1-9. https://doi.org/10.1016/j.jairtraman.2017.02.004

Kretschmer, B., Narita, D., \& Peterson, S. (2009). The economic effects of the EU biofuel target. Energy Economics, 31, S285-S294. https://doi.org/10.1016/j.eneco.2009.07.008

Lee, D. S., Fahey, D. W., Forster, P. M., Newton, P. J., Wit, R. C., Lim, L. L., ... Sausen, R., (2009). Aviation and global climate change in the 21st century. Atmospheric Environment, 43(22), 3520-3537. https://doi.org/10.1016/j.atmosenv.2009.04.024

Mahwood, B., Gazis, E., Hoefnagels, R., \& Jong, S. D. (2015). Technology and Commercial Maturity of Aviation Biofuels. 14th International Conference on Sustainable Energy Technologies, Nottingham, UK.

Markets Insider. (2019). CO2 European Emission Allowances. Retrieved September 20, 2019, from 
https://markets.businessinsider.com/commodities/co2-european-emission-allowances

Murphy, F., Li, N., Murphy, B., \& Cummins, M. (2013). The link between jet fuel prices, carbon credits and airline firm value. Journal of Energy Markets, 6(2), 83-97. https://doi.org/10.21314/JEM.2013.090

Penner, J. E., Lister, D. H., Griggs, D. J., Dokken, D. J., \& McFarland, M. (2009). Aviation and the Global Atmosphere: Summary for Policymakers. IPCC Special Report. Brussels, Belgium, Intergovernmental Panel on Climate Change.

Perlack, R. D., \& Stokes, B. J. (2011). U.S. billion-ton update: Biomass supply for a bioenergy and bioproducts industry. U.S. DOE (Department of Energy). Oak Ridge National Laboratory, Oak Ridge, TN, ORNL/TM-2011/224.

Richard, T. L. (2010). Challenges in scaling up biofuels infrastructure. Science, 329, 793-796, 799. https://doi.org/10.1126/science.1189139

Roosevelt, M. (2007, December). Aircraft Emission Cuts Urged. Los Angeles Times, 1A, 2A.

Scown, C. D., Horvath, A., \& McKone, T. E. (2011). Water footprint of U.S. transportation fuels. Environmental Science \& Technology, 45(7), 2541-2553. https://doi.org/10.1021/es102633h

Searchinger, T., Heimlich, R., Houghton, R. A., Dong, F., Elobeid, A., Fabiosa, J., Tokgoz, S., ... Yu, T. H. (2008). Use of U.S. croplands for biofuels increases greenhouse gases through emissions from land-use change. Science, 319, 1238-1240. https://doi.org/10.1126/science.1151861

Seber, G., Malina, R., Pearlson, M. N., Olcay, H., Hileman, J. I., \& Barrett, S. R. (2014). Environmental and economic assessment of producing hydroprocessed jet and diesel fuel from waste oils and tallow. Biomass and Bioenergy, 67, 108-118. https://doi.org/10.1186/s13068-017-0945-3

Serra, T., \& Zilberman, D. (2013). Biofuel-related price transmission literature: A review. Energy Economics, 37, 141-151 https://doi.org/10.1016/j.eneco.2013.02.014

Staples, M. D., Olcay, H., Malina, R., Trivedi, P., Pearlson, M. N., Strzepek, K., ... Barrett, S. R. (2013). Water consumption footprint and land requirements of large-scale alternative diesel and jet fuel production. Environmental Science \& Technology, 47, 12557-12565. https://doi.org/10.1021/es4030782

Steiner, J. J., Lewis, K. C., Baumes, H. S., \& Brown, N. L. (2012). A feedstock readiness level tool to complement the aviation industry fuel readiness level tool. Bioenergy Research, 5(2), 492-503. https://doi.org/10.1007/s12155-012-9187-1

Stratton, R. W., Wong, H. M., \& Hilerman, J. I. (2010). Life Cycle Greenhouse Gas Emissions from Alternative Jet Fuels. Massachusetts Institute of Technology and Partnership for Air Transportation Noise and Emissions Reduction.

Wald, M. L., \& Kanter, J. (2007, November). Plan to Cut Jet Pollution Is Approved in Europe. New York Times.

Winchester, N., Malinab, R., Staples, M. D., \& Barrett, S. R. H. (2014). The impact of advanced biofuels on aviation emission and operations. Retrieved February 8, 2017, from http://www.sciencedirect.com/science/article/pii/S0140988315001164

World Bank Group. (2015, September). State and Trends of Carbon Pricing.

\section{Notes}

Note 1. EPA's Final Endangerment finding is the scientific evidence that greenhouse gases cause climate change.

Note 2. Total anthropogenic radiative forcing is the radiative effect (the difference between the amount of energy absorbed by the Earth and that reflected) as a result of human activity.

Note 3. Well to wake GHG emissions is a lifecycle analysis of greenhouse gases from the extraction and recovery of the feedstock to its transport, to the production of fuel, its transport and then its combustion.

\section{Copyrights}

Copyright for this article is retained by the author, with first publication rights granted to the journal.

This is an open-access article distributed under the terms and conditions of the Creative Commons Attribution license (http://creativecommons.org/licenses/by/4.0/). 